\title{
Persistence of the Landes ecotype of Apis mellifera mellifera in southwest France: confirmation of a locally adaptive annual brood cycle trait*
}

\author{
James P. STRANGE ${ }^{\mathrm{a}}$, Lionel GARNERY ${ }^{\mathrm{b}, \mathrm{c}}$, Walter S. SHEPPARD ${ }^{\mathrm{a}}$ \\ ${ }^{a}$ Department of Entomology, Washington State University, Pullman Washington, 99164-6382, USA \\ b Laboratoire Populations, Génétique et Évolution, Centre National de la Recherche Scientifique, 91198 \\ Gif-sur-Yvette, France \\ ${ }^{\mathrm{c}}$ Université de Versailles-St-Quentin-en-Yvelines, Versailles, France
}

Received 24 October 2005 - Revised 9 October 2006 - Accepted 11 October 2006

\begin{abstract}
In 1966, an ecotype of honey bees in France was described as adapted to the local floral phenology. Colonies in the Landes region had a bimodal peak in annual colony brood cycle, one peak in early summer and one in autumn. This brood cycle was determined to be of genetic origin. While many beekeepers in this region cultivate the locally adapted bee, some beekeepers import stock from elsewhere in Europe. These importations led to concerns that the genetic character of the ecotype could be lost due to genetic introgression. We established two research apiaries in the center of the Landes region and measured brood area bi-weekly to assess colonies for the brood cycle trait. We observed the timing of drone production, and the timing and number of virgin queens produced. Brood cycle data from the current study were compared to data from the initial work on the Landes ecotype. Of the colonies tested, $48.3 \%$ had a brood cycle similar to the cycle described in 1966. Implications for conservation are discussed.
\end{abstract}

Apis mellifera mellifera / conservation biology / time series analysis / ecotype / annual colony cycle

\section{INTRODUCTION}

Apis mellifera $\mathrm{L}$. forages on a wide variety of plant species for pollen and nectar and is not considered to specialize on a single food source. Despite this polylectic foraging behavior, specific behavioral and phenological adaptations to local environmental conditions are known for some populations throughout the range of the honey bee (Ruttner, 1988; Ruttner et al., 1990). These locally adapted populations or ecotypes have evolved traits that confer selective advantage to the population within an ecologically distinct area, although outside the range of the ecotype these

Corresponding author: W.S. Sheppard, shepp@mail.wsu.edu

* Manuscript editor: Jacqueline Pierre traits may be detrimental. While local adaptations can occur, human mediated movement of honey bee colonies for honey production and agricultural pollination dispersed $\mathrm{A}$. mellifera subspecies that may be more generally adapted to a wide variety of ecological settings (Ruttner et al., 1990). Cultivation of various honey bee subspecies for apicultural purposes has occurred both in areas previously free of Apis (e.g., the Americas and Australia) and within the original range of A. mellifera. In the latter case, establishment of these subspecies within the geographic ranges of other subspecies or ecotypes may lead to hybridization with the native populations (Garnery et al., 1998a, b) or, for subspecies having limited areas of endemism, actually threaten their survival (Ruttner et al., 1990; Sheppard et al., 1997; De La Rúa et al., 2003). De La Rúa et al. 
(2003) demonstrated that recent introductions of honey bees to supplement island populations of A. m. iberica depleted by Varroa destructor Anderson and Truman mites resulted in significant genetic introgression. Additionally, in many areas there has been a resurgence of interest in working with locally adapted bee stocks, which may have traits advantageous to bee culture in the region.

Louveaux et al. (1966) described behavioral differences in several A. mellifera populations in France, designated as ecotypes of the subspecies A. m. mellifera. One of the ecotypes, in the Landes of southwest France, inhabited a coastal plain stretching from Bordeaux south and east from the Atlantic to the city of Mont de Marsan. The regional flora was dominated by two major nectar producing plants, alder buckthorn (Rhamnus frangula L.) in late May through early June and common heather (Calluna vulgaris L.) in September. By measuring the area of brood (developing larval and pupal bees) monthly throughout the season, Louveaux et al. (1966) were able to show that the colony produced more bees to coincide with these periods of high food availability. Specifically, they found that brood production increased slowly in the springtime, peaking immediately before the flowering of the black alder in May. After the black alder bloom, brood production decreased in late June and July, but increased again preceding the heather bloom in August.

Subsequently, Louveaux (1973) moved several colonies of the Landes ecotype several hundred kilometers north to Bures-sur-Yvette, France and observed the same annual colony cycle, independent of location and to the detriment of the colony. While a late season colony population increase was beneficial in the presence of the heavily producing heather plant, it was maladaptive without a late season food source and Louveaux had difficulty keeping this ecotype alive in Bures-sur-Yvette. Furthermore, non-ecotypic colonies from the Paris Basin did not develop the ecotypic annual colony cycle when moved to the Landes. From 1966-1972 Louveaux (1973) made a series of genetic crosses between ecotypic and non-ecotypic bees. He found that intermediates in the annual brood cycle could be produced, and thus concluded that the brood cycle was genetically determined. Cornuet et al. (1982) performed a limited morphological analysis of the Landes population and found several characters in the ecotype to be significantly different from other populations of A. m. mellifera in France.

Due to the profitability of heather honey, several thousand colonies are brought to the Landes from elsewhere in France every autumn to exploit this honey crop (Odoux and Garnery, 1995; Strange, 2003). In addition to the transient movement of colonies within a year, several hundred colonies of non-native honey bees are maintained permanently by beekeepers within the Landes region (Perrier, 2001; Perrier et al., 2003). Perrier et al. (2003) used microsatellites and mitochondrial DNA markers to show low levels of genetic introgression from imported stock into the local population. A significant spatial partitioning of the region was found in that apiaries could be grouped into "local" and "imported". Mitochondrial introgression from imported stock to local stock was found to be $1.66 \%$ and nuclear introgression was observed to be $3.09 \%$ (ibid). These results indicated that, despite the culture of imported colonies in the region, little hybridization with the ecotype had occurred, suggesting that the Landes ecotype described by Louveaux might still be a viable population. The aim of the present study was to assess colonies in the Landes region for the annual brood cycle trait described by Louveaux et al. (1966) and to identify colonies that could be used as breeder stock for genetic conservation of the ecotype. Furthermore, we sought to identify colonies exhibiting the ecotypic phenology for further genetic study, thus allowing for better interpretations of previous molecular studies conducted in the Landes region.

\section{MATERIALS AND METHODS}

\subsection{Experimental design}

In March 2002, we established two apiaries containing a total of 51 colonies (44 local colonies and 7 control colonies) in the Landes in southwest France in cooperation with two local beekeepers. 
The research apiaries were located $15 \mathrm{~km}$ apart with 27 colonies located at one site and 24 colonies located at the other site. The local colonies were from stocks identified by beekeepers as "native black bees" and the control colonies were hybrid stock purchased from a source outside of the Landes, near Pau, France. All colonies underwent normal management for honey production, although queens were restricted to the bottom two boxes by means of a queen excluder to prevent expansion of the brood nest into the honey supers. Colonies received no supplemental feeding during the experiment.

\subsection{Brood area measurement}

Every two weeks, colonies were examined and each frame containing brood was photographed with a tripod mounted digital camera (Hewlett-Packard Photosmart 712). Before photographs were taken, the frame was placed onto a fixed stand and labeled with the hive number on a standard sized card $(5 \mathrm{~cm}$ by $10 \mathrm{~cm})$. The photographs were taken from a standard distance of $50 \mathrm{~cm}$, to insure proper calibration for brood area in the digital analysis software. After photography, frames were replaced in the colonies.

Images were transferred to a computer and brood area was measured using Scion Image v.4.0.2 $₫$ image analysis software (Scion Image, 2001). Images were size-calibrated using the standardized card on each frame, and the total area of capped worker and drone brood was measured for each colony. These data were used to build the annual worker brood cycle and annual drone brood cycle curves for each colony. Hereafter, the annual worker brood cycle is referred to as the annual brood cycle unless indicated otherwise. In addition to the measurements, the reproductive status of the colony was measured. Queen cell numbers were recorded along with the status of emerged gynes and reproductive swarming. These measurements continued until November 2002, when brood rearing had ceased in the colonies.

\subsection{Data analysis}

The annual brood cycle data were transformed by an $\ln$ (brood area +1 ) transformation to normalize the data. The data were converted to a time series by subtracting the value for one date from the value for the following sampling date $\left(T_{2}-T_{1}\right.$;
$\left.\mathrm{T}_{3}-\mathrm{T}_{2} ; \ldots ; \mathrm{T}_{n}-\mathrm{T}_{n-1}\right)$. This gave a positive value for an increase in brood production and a negative value for a contraction in the brood area. This method allowed the comparison of relatively large colonies to relatively small colonies. These data were compared by means of a Chi-square goodness-of-fit test to data Louveaux et al. (1966) used to describe the Landes ecotype. The level of significance was set at $P<0.05$.

Drone brood area was calculated in the same manner as the worker brood area for colonies expressing the annual brood cycle trait of the Landes ecotype.

\subsection{Colony weight gain}

Colonies at one research apiary were weighted at 12 day intervals during the black alder $(R$. frangula) honey flow in early June and weekly during the heather (C. vulgaris) honey flow from the second week of September through the second week of October (29 days). These periods corresponded roughly to the period of nectar availability from each source. Average daily weight gain was calculated for each colony in the early season period and the late season period by dividing the total weight gained (or lost) by the number of days. Colonies were assigned to one of three groups based upon the results of the brood cycle analysis: ecotype, nonecotype and control. For the early season period there were 22 colonies ( $n=7$ ecotype, $n=8$ non-ecotype, $n=7$ control) were analyzed while 16 colonies ( $n=7$ ecotype, $n=5$ non-ecotype, $n=4$ control) were analyzed during the late season period. A one-way ANOVA was used to compare differences in daily weight gain among the three groups within the two periods. Means for groups of colonies within the separate periods were compared with LSD multiple means comparisons with significance set at the 0.05 level. Tests were computed using SPSS v12.1 software (2003).

\section{RESULTS}

\subsection{Annual brood cycle}

Of the 51 research colonies, 15 were removed during the course of the experiment due to queenlessness, detection of disease symptoms or beekeeper whim and were not included in the analysis. Two of the control 
Table I. $\chi^{2}$ values and significance $(P<0.05$, $\mathrm{df}=5, \mathrm{CV}=15.086$ ) for 29 colonies of local origin and 5 control colonies of foreign origin as compared with a Pearson Goodness-of-Fit test to data from Louveaux et al. (1966). The final column notes colonies that had extended broodless periods (y) during the 2002 season. Values significantly different from Louveaux et al. (1966) are denoted with $* *$.

\begin{tabular}{|c|c|c|}
\hline Colony & $\chi^{2}$ & Broodless \\
\hline 1 & $651.637 * *$ & $\mathrm{y}$ \\
\hline 2 & 2.970 & \\
\hline 3 & 1.567 & \\
\hline 4 & 3.576 & \\
\hline 5 & 0.952 & \\
\hline 6 & 3.496 & \\
\hline 7 & 13.555 & \\
\hline 8 & 2.624 & \\
\hline 9 & $470.642 * *$ & y \\
\hline 10 & $456.093 * *$ & y \\
\hline 11 & $198.557 * *$ & y \\
\hline 12 & 13.637 & \\
\hline 13 & 1.360 & \\
\hline 14 & $30.787 * *$ & \\
\hline 15 & $376.169 * *$ & y \\
\hline 16 & 6.003 & \\
\hline 17 & 2.355 & \\
\hline 18 & 1.879 & \\
\hline 19 & $271.585^{* *}$ & y \\
\hline 20 & $505.867 * *$ & y \\
\hline 21 & $26.697 * *$ & $\mathrm{y}$ \\
\hline 22 & $40.200 * *$ & y \\
\hline 23 & $445.219 * *$ & y \\
\hline 24 & 1.405 & \\
\hline 25 & $611.036^{* *}$ & y \\
\hline 26 & $67.757 * *$ & y \\
\hline 27 & $85.559 * *$ & y \\
\hline 28 & $647.952 * *$ & y \\
\hline 29 & 5.139 & \\
\hline Control 1 & $33.815^{* *}$ & \\
\hline Control 2 & $27.810 * *$ & \\
\hline Control 3 & $39.433 * *$ & \\
\hline Control 4 & $30.542 * *$ & \\
\hline Control 5 & $38.966 * *$ & \\
\hline
\end{tabular}

colonies died during the course of the experiment and were also excluded from analysis. Of the 29 "native black bee" colonies remaining in the experiment in November 2002, 14 $(48.3 \%)$ had an annual brood cycle typical of the Landes ecotype described by Louveaux et al. (1966) (Tab. I). Furthermore, of the 15 remaining colonies that originated from the Landes population and did not have the ecotypic brood pattern, 14 had prolonged broodless periods (more than 2 weeks). The broodless periods in these non-ecotypic Landes bees occurred following swarming events (unpublished data) in which the transition from mother queen to daughter queen was sufficiently long to result in periods with no capped brood.

The mean worker brood cycle (Fig. 1) defined a posteriori as belonging to the Landes ecotype $(n=14)$ began in early spring with no brood in the over wintered colony and brood area gradually increased in a linear fashion until the last week in May (Week 21). The brood area remained large, but gradually decreased until mid-August. Thereafter, brood area increased again to early summer levels until the third week of September. Subsequently, brood rearing ceased quickly, going from very high levels of brood to no brood in less than a month.

\subsection{Brood cycle of reproductives}

The cycle of drone brood production by ecotype colonies ( $n=14$ ) (Fig. 2) was characterized by a rapid increase in drone production from mid-April until early June. This early season peak in drone production was followed by a decrease in drone rearing through midAugust, when drone production increased until mid-September. By contrast, control colony drone brood production peaked in early April and diminished slowly until ceasing in late June. As Louveaux et al. (1966) neither quantified drone production nor swarming phenology, no comparison of our results could be made with published data.

Queen production in all local colonies $(n=29)$ sampled throughout the year (Fig. 3) 

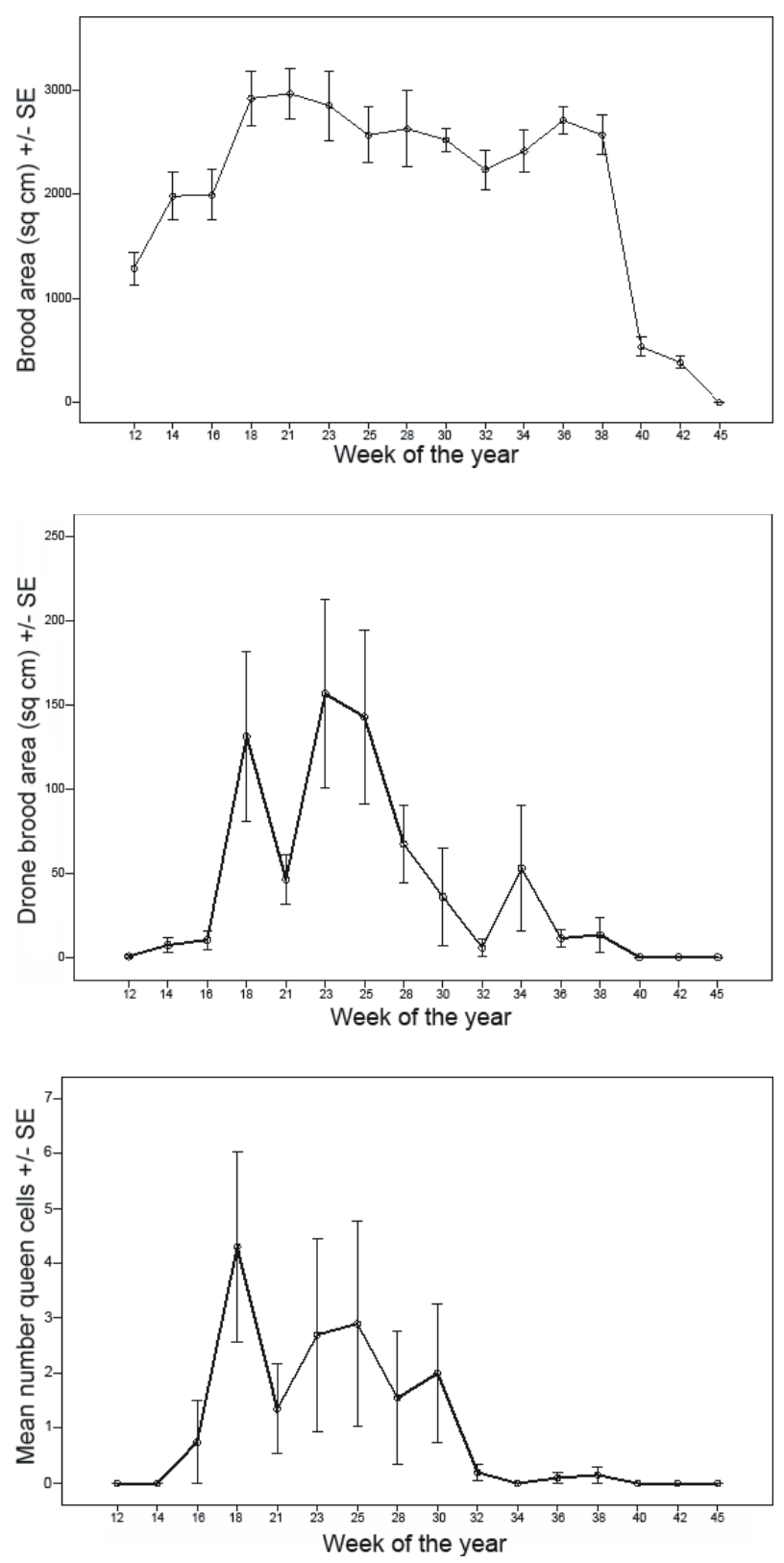

Figure 1. Annual brood cycle of 14 ecotypic colonies at both research apiaries. Values are mean brood area $\left(\mathrm{cm}^{2}\right) \pm$ the standard error of the mean. Week on the horizontal axis is the weeks of the year.

Figure 2. Area of drone brood in $\mathrm{cm}^{2}$ for colonies $(n=14)$ exhibiting ecotypic brood pattern \pm the standard error of the mean. Weeks on the horizontal axis represent the weeks of the year.

Figure 3. Mean number of queen cells produced \pm standard error of the mean on all colonies $(n=29)$ identified as "local bees" by the beekeeper. Weeks on the horizontal axis represent the weeks of the year. began in late April, with the period of highest production in early May. The production of queens and swarming events in the apiaries continued into July and corresponded well to the period of drone production (Fig. 2). No queen cell production was observed in the control colonies.

\subsection{Colony weight gain}

The one-way ANOVA on average daily weight gain during the early June nectar flow of alder buckthorn indicated that there was no effect of group on weight gain $\left(\mathrm{F}_{2,21}=1.639\right.$, $P=0.221)$. The ecotype, non-ecotype and 



Figure 4. Average daily weight gain in kilograms of colonies grouped by ecotypic and non-ecotypic brood cycles for two nectar flow events, spring $(n=22)$ and fall $(n=16)$. Error bars represent standard error of the mean and significance is indicated by letter. Post hoc mean comparisons are within nectar flows and not between them and significance is at the $P<0.05$ level.

control colonies gained $268 \mathrm{~g}, 606 \mathrm{~g}$ and $650 \mathrm{~g}$ of weight per day, respectively (Fig. 4). During the late season period of the heather bloom, the one way ANOVA showed a significant effect of group on average daily weight gain $\left(\mathrm{F}_{2,15}=5.894, P=0.015\right)$. The LSD test indicated that ecotype colonies gained significantly more weight per day during the fall nectar flow (C. vulgaris) than the control colonies $(P=0.005)$ but not significantly more than the non-ecotype colonies $(P=0.081)$. Nonecotype and control colonies did not have significantly different weight gains $(P=0.157)$. The ecotype, non-ecotype and control colonies gained $335 \mathrm{~g}, 149 \mathrm{~g}$, and $31 \mathrm{~g}$ of weight per day during the $C$. vulgaris bloom, respectively (Fig. 4).

\section{DISCUSSION}

Conservation of geographic races of $\mathrm{A}$. $\mathrm{mel}$ lifera was proposed by Ruttner et al. (1990) in response to observed hybridization of local bee stocks with imported stock. However, to date little has been done to further this goal. With the advent of molecular techniques to monitor genetic introgression, hybridization has been documented among honey bee populations that were originally genetically distinct (Estoup et al., 1995; Franck et al., 1998; De La Rúa et al., 2001, 2002, 2003). Extensive importation and within-country movement of honey bees continues to occur in many regions. Losses of colonies to $V$. destructor have increased the pressure on beekeepers to import stocks, especially in places where populations are decimated (De La Rúa et al., 2003). While some populations inhabit easily defined geographic areas (e.g., islands, oases, the Nile river valley); others are less isolated and stock importation may endanger the genetic integrity of local populations (Ruttner et al., 1978; Ruttner, 1988; Sheppard et al., 1997; De La Rúa, 2003). Additionally, the adaptive characteristics of bees from many regions are poorly studied making it difficult to rapidly implement conservation efforts.

Despite the importation of non-native honey bee colonies into the Landes region, annual colony cycle data from our study demonstrate the persistence of the Landes ecotype. While the frequency of the ecotypic annual brood cycle trait in the Landes population was 
less than $100 \%$, the persistence of the trait despite significant movement of colonies into the region for heather honey production and the year round culture of non-native stock in the region is encouraging for future conservation efforts. Most (93.3\%) of the "native black bee" colonies that did not show the ecotypic brood cycle had a prolonged broodless period following swarming events during the study period. This resulted when the colony swarmed and the daughter queen did not commence egg laying quickly, thus resulting in a gap in the annual brood cycle. It is possible that many of these colonies were actually ecotype colonies, but the interruption of the annual brood cycle by swarming and the subsequent affect on capped brood area limited the ability of the goodness-of-fit tests to correctly classify these colonies. That interpretation would fit well with the findings of Perrier et al. (2003) who found a low level of genetic introgression in the Landes. Because of the difficulty of obtaining detailed brood cycle data and the need to easily identify ecotype colonies for conservation, it will be useful to develop morphometric and molecular tools for discrimination of the Landes ecotype.

It is unlikely that the ecotypic annual brood cycle ever occurred in all of the colonies in the Landes region in a given year. Without a more complete set of historical data, which includes individual colony records it is impossible to know the exact frequency of the trait in the population in the past. Most likely, genetic and environmental variation from year to year would result in a range of phenologies around the mean annual brood cycle that Louveaux et al. (1966) reported. Additionally, the frequency of swarming events (14 of 29 Landes colonies in 2002) in the Landes population suggest that the optimal sampling of the annual brood cycle be conducted over multiple years for any one colony to determine the exact effects of swarming and subsequent broodless periods on the Goodness-of-Fit test.

The differences in weight gain of colonies supports the hypothesis of Louveaux et al. (1966) that the late season peak in brood production has evolved to exploit the heather bloom in the region. The fact that control colonies performed equal to the ecotype colonies in the early season, but not in the late season helps illustrate the importance of the timing of brood production to honey hoarding. The ecotype colonies which began increasing brood production in August were able to muster more workers for foraging late in the season and had a correspondingly higher average daily weight gain. The weight gain occurred after the peak in brood production and during the time of highest weight gain in mid-September through mid-October, the ecotype colonies had decreasing amounts of brood area. Observations in the ecotype colonies at that time indicated that workers were storing the collected nectar in the brood area which effectively reduced the number of cells into which the queen could oviposit. This may account for the precipitous decrease in brood area observed during the heather nectar flow.

Beekeepers that operate within the Parc Régional Naturel des Landes de Gascogne have formed a cooperative focused on preserving the genetic character of the Landes ecotype. Through selective breeding of colonies that exhibit the annual colony cycle associated with the Landes ecotype, it should be possible to increase the frequency of this trait in the honey bee population in the region. Because most beekeepers in the region produce their own queens or increase stock by splitting colonies, the results of the present study will be useful in controlling introgression. Specifically, timing colony divisions to increase stock numbers in June would coincide with the emergence of the highest number of ecotype drones. Swarms that are collected before June would be less likely to come from ecotype sources and their queens can be replaced with selected stock.

Beekeepers that choose to work with non-local imported stocks are also part of the Landes de Gascogne conservation effort. Their assistance to reduce unintended genetic introgression may include the siting of apiaries to maintain isolation of the ecotype in specific mating areas. Dialogue and inclusion of all beekeeping interests in the cooperative conservation program underway on behalf of the Landes ecotype honey bee could serve as a model for other regional honey bee conservation efforts. 


\section{ACKNOWLEDGEMENTS}

We thank Ludo Lemaire, Jean-Claude Ducam, Martin Irazoqui and Gilles Fert for providing experimental colonies and graciously donating time, equipment and expertise to the research. We thank Jennifer and Amelia Strange for assistance with data collection. We thank the François Billy and the Parc Régional Naturel des Landes de Gascogne for providing staff and funding for this project. Additional funding was provided by the Centre National de la Recherche Scientifique, Washington State University and the Washington State Beekeepers Association.

Persistence de l'écotype Landes d'Apis mellifera mellifera dans le sud-ouest de la France : confirmation d'un cycle de couvain annuel adapté aux conditions locales.

Apis mellifera mellifera / biologie de la conservation / analyse de séries temporelles / écotype / cycle annuel de la colonie

Zusammenfassung - Fortbestehen des Landes Ökotyps von Apis mellifera mellifera in Südwest-Frankreich: Bestätigung eines an die lokalen Bedingungen angepassten jährlichen Brutzyklus. Im Jahr 1966 beschrieb Louveaux eine Honigbienen-Population in Südwest-Frankreich, die extrem an die Phänologie der lokalen Blütenpflanzen angepasst war. Die Bienenvölker in dieser Region zeigten zwei Höhepunkte im jährlichen Brutzyklus. Beide Peaks fielen zeitlich mit einem auffälligen Auftreten von blühenden Pflanzen im Frühsommer bzw. im Herbst zusammen. Dieser Brutzyklus wurde in keiner anderen Region Frankreichs beobachtet und hatte genetische Ursachen. Während viele Imker in dieser Region nach wie vor diese lokal angepasste Biene halten, haben verschiedene Berufsimker während der letzten 39 Jahre Bienenvölker aus anderen Gebieten Europas importiert. Diese Importe und der Verlust an wildlebenden Bienenvölkern durch die parasitische Milbe Varroa destructor ließ befürchten, dass die charakteristischen Eigenschaften der lokalen Population durch genetische Introgression verloren gehen könnten. Wir errichteten zwei Versuchs-Bienenstände im Zentrum der Region Landes und erfassten die Brutfläche zweimal pro Woche, um den jährlichen Brutzyklus der Bienenvölker zu überprüfen. Zusätzlich wurden die Zeitpunkte für das Schwärmen und der Produktion von Drohnenbrut und die Anzahl der unbegatteten Jungköniginnen erfasst. Die hier ermittelten Daten für den Brutzyklus (Abb. 1) wurden mit den Daten von Louveaux aus dem Jahr 1966 mit einem
goodness-of-fit-Test verglichen. Von den geprüften Bienenvölkern zeigten 48,3 \% einen Brutverlauf, der sich statistisch nicht von dem von Louveaux beschriebenen unterschied (Tab. I). Wenn man Völker mit ausgedehnten brutlosen Phasen aufgrund von Umweiselungen oder Schwärmen bei der Analyse nicht berücksichtigt, steigt der Anteil von Völkern mit dem für den Ökotyp charakteristischen Brutzyklus sogar auf 93,3\%. Die Populationsdynamik der Drohnenbrut (Abb. 2) und die Produktion von Weiselzellen ähnelten dem Verlauf der Arbeiterinnenbrut. Diese Ergebnisse werden in Landes dazu benützt, um zusammen mit den Imkern der Region ein Programm zur Erhaltung der charakteristischen genetischen Eigenschaften des Landes-Ökotyps zu errichten.

Apis mellifera mellifera / Naturschutz / Zeitreihen Analysen / Ökotyp / Volksentwicklung im Jahreverlauf

\section{REFERENCES}

Cornuet J.M., Albisetti J., Mallet N., Fresnaye J. (1982) Étude Biométrique d'une population d'abeilles Landaises, Apidologie 13, 3-13.

De La Rúa P., Galián J., Serrano J., Moritz R.F.A. (2001) Genetic structure and distinctiveness of Apis mellifera L. populations from the Canary Islands, Mol. Ecol. 10, 1733-1742.

De La Rúa P., Serrano J., Galián J. (2002) Biodiversity of Apis mellifera populations from Tenerife (Canary Islands) and hybridization with East European races, Biodivers. Conserv. 11, 59-67.

De La Rúa P., Galián J., Serrano J., Moritz R.F.A. (2003) Genetic structure of Balearic honeybee populations based on microsatellite polymorphism, Genet. Sel. Evol. 35, 339-350.

Estoup A., Garnery L., Solignac M., Cornuet J.M. (1995) Microsatellite variation in honey bee (Apis mellifera L.) populations: hierarchical genetic structure and test of the infinite allele and stepwise mutation models, Genetics 140, 679-695.

Franck P., Garnery L., Solignac M., Cornuet J.M. (1998) The origin of west European subspecies of honeybees (Apis mellifera): New insights from microsatellite and mitochondrial data, Evolution 52, 1119-1134.

Garnery L., Franck P., Baudry E., Vautrin D., Cornuet J.M., Solignac M. (1998a) Genetic diversity of the west European honey bee (Apis mellifera mellifera and A. m. iberica). I. Mitochondrial DNA, Genet. Sel. Evol. 30, S31-S47.

Garnery L., Franck P., Baudry E., Vautrin D., Cornuet J.M., Solignac M. (1998b) Genetic diversity of the west European honey bee (Apis mellifera mellifera and A. m. iberica). II. Microsatellite loci, Genet. Sel. Evol. 30, S49-S74. 
Louveaux J. (1973) The acclimatization of bees to a heather region, Bee World 54, 105-111.

Louveaux J., Albisetti M., Delangue M., Theurkauff M. (1966) Les modalités de l'adaptation des abeilles (Apis mellifica L.) au milieu naturel, Ann. Abeille 9, 323-350.

Odoux J.F., Garnery L. (1995) Recherche d'abeilles de types locaux en France, Bull. Tech. Apic. 22, 83-88.

Perrier C. (2001) Contribution des outils moléculaires à la gestion et à la conservation d'une population landaise d'abeilles domestique A. mellifera, Diplôme d'études scientifiques spécialisées gestion de la biodiversité, Université Paris IV.

Perrier C., Strange J., Langella O., Sheppard W.S., Garnery L. (2003) Diversité génétique, introgressions mitochondriales et nucléaires dans une population d'abeilles des Landes de Gascogne, Actes du Bureau de Recherches Génétiques 4, 79-100.
Ruttner F. (1988) Biogeography and Taxonomy of Honeybees, Springer-Verlag, HeidlebergNew York.

Ruttner F., Milner E., Dews J.E. (1990) The Dark European Honey Bee Apis mellifera mellifera Linnaeus 1758, British Isles Bee Breeders Association

Ruttner F., Tassencourt L., Louveaux J. (1978) Biometrical-statistical analysis of the geographic variability of Apis mellifera L. 1. Materials and Methods, Apidologie 9, 363-381.

Scion Image (2001) v4.0.2, Scion Corporation.

Sheppard W.S., Arias M.C., Grech A., Meixner M.D. (1997) Apis mellifera ruttneri, a new honey bee subspecies from Malta, Apidologie 28, 287-293.

SPSS v12.1. (2003) SPSS Inc. Chicago, IL

Strange J.P. (2003) The Bournacq hive, Bee Culture $131,20-23$. 